\title{
Obstructive Jaundice Due To Migration of Suture Material Into Common Bile Duct: A Very Rare Presentation
}

\author{
Sandeep Kumar Agarwal ${ }^{1}$, Marshal D Kerketta ${ }^{1}$, Anjana Gandhi ${ }^{1}$, Sanjay Kumar Yadav ${ }^{1 *}$, Abhinav Anand ${ }^{1}$, Om \\ Prakash $^{1}$, Satish Kumar ${ }^{1}$ \\ ${ }^{1}$ deptt. Of General Surgery Rajendra Institute Of Medical Sciences Ranchi, Jharkhand- 834009
}

\begin{abstract}
Few cases have been reported in literature wherein patient presented with stone in CBD after many years of open cholecystectomy where suture material migrated formed the nidus for stone formation. Here we are reporting an interesting case where patient presented with obstructive jaundice within a month after open cholecystectomy. Upon CBD exploration there was non absorbable suture material inside the lumen of CBD which was removed and jaundice subsided.
\end{abstract}

Keywords: Cholecystectomy, Obstructive jaundice, Common bile duct(CBD), suture material

\section{Introduction:}

Commonly reported complications of cholecystectomy include damage to the common bile duct [1], bile leaks from the gallbladder bed or cystic duct stump [2], dropped gallstones [3], and damage to other structures such as the small bowel, liver, or diaphragm [4].Post cholecystectomy obstructive jaundice is well documented in literature butCommon bile duct (CBD) is a rare site for foreign bodies (FB), which may lead to obstructive jaundice. Even in these cases it is formation of stone around nidus of foreign body which causes biliary obstruction. But in our case foreign body itself lead to obstruction within 15 days after cholecystectomy.

\section{Case Summary:}

A 26 years old female patient was admitted with single gall bladder calculus with normal CBD. Her liver function tests and other routine investigations were within normal limits. Open cholecystectomy done and post op period was uneventful.

She developed jaundice on $15^{\text {th }}$ post op day . On examination she was icteric with LFT was done and her S. Bilirubin was 32mg/dl( Direct bilirubin- $19.06 \mathrm{mg} / \mathrm{dl}$ ), ALP 512 u/l, S.G.P.T. 105 U/L and S.G.O.T. 225 $\mathrm{U} / \mathrm{L}$.

Upon MRCP, there was proximal dilatation of CBD with abrupt narrowing at mid CBD and distal CBD was not visualized s/o stricture(??).Repeat LFT was done after 5 days and S. Bilirubin level came down to 15.0 $\mathrm{mg} / \mathrm{dl}($ Direct Bilirubin $7.51 \mathrm{mg} / \mathrm{dl}$ ), ALP $365 \mathrm{U} / \mathrm{L}$.

Her S. Bilirubin raised to $35 \mathrm{mg} / \mathrm{dl}$ and ALP $712 \mathrm{U} / \mathrm{L}$ after 2 wks.Upon exploration, CBD was normal in calibre and no stone was palpable. CBD was opened just above the cystic duct opening and non absorbable suture material was retrieved from within the lumen of CBD.[ FIGURE $1 \& 2$ ]. T- tube was given. Post operative period was uneventful and patient was discharged on $15^{\text {th }}$ post op day after T-Tube cholangiogram, which showed dye in duodenum.

\section{Discussion:}

Obstructive jaundice due to foreign body in CBD receives very little attention by surgeons because they are very rare. Exact phenomena of migration is not understood well.Ban et al., in a review of63 patients with foreign bodies in their biliarytracts during the past 75 years, report the mostfrequently encountered foreign bodies to beresiduals from previous operations such as suturematerials and endoclips[5]. One study had reported the migration rate of the surgical clips after LC to be $24 \%$ [6].

Cimsit et all reported a case in which surgical gauze was removed by CBD exploration[7].

Ours is probably the first case of obstructive jaundice due to suture knot in CBD after open cholecystectomy. Most plausible explanation can be migration of cystic duct ligature into the CBD.

Endoscopic sphincterotomy can be diagnostic and is also advocated as procedure of choice for extraction of foreign bodies within CBD.

In post operative patients presenting with obstructive jaundice, possibility of foreign body should be borne in mind. 


\section{References:}

[1] S. B. Archer, D. W. Brown, C. D. Smith, G. D. Branum, and J. G. Hunter, "Bile duct injury during laparoscopic cholecystectomy: results of a national survey," Annals of Surgery, vol. 234, no. 4, pp. 549-559, 2001. View at Publisher - View at Google Scholar

[2] S. Eisenstein, A. J. Greenstein, U. Kim, and C. M. Divino, "Cystic duct stump leaks: after the learning curve," Archives of Surgery, vol. 143, no. 12, pp. 1178-1183, 2008. View at Publisher · View at Google Scholar · View at PubMed

[3] A. R. Tumer, Y. N. Yüksek, A. C. Yasti, U. Gözalan, and N. A. Kama, "Dropped gallstones during laparoscopic cholesystectomy: the consequences," World Journal of Surgery, vol. 29, no. 4, pp. 437-440, 2005. View at Publisher - View at Google Scholar . View at PubMed

[4] G. N. Marakis, T. E. Pavlidis, K. Ballas, et al., "Major complications during laparoscopic cholecystectomy,” International Surgery, vol. 92 , no. 3, pp. 142-146, 2007.

[5] Ban JL, Hirose FM, Benfield JR. Foreign bodies of the biliary tract: report of two patients and a review of the literature. Ann Surg. 1972; 176: $102-107$.

[6] Lombardo F, Cetta F, Cappelli A. The long-term fate ofmetallic clips used for cystic duct and artery ligation duringlaparoscopic cholecystectomy. Gastroenterol 1994; 17:542-4.

[7] Cimsit B, Keskin M, Ozden I, Alper A.Obstructive jaundice due to a textiloma mimicking a common bile duct stone.J HepatobiliaryPancreat Surg. 2006;13(2):172

FIGURE-1 Intra op picture

FIGURE-2 suture knot
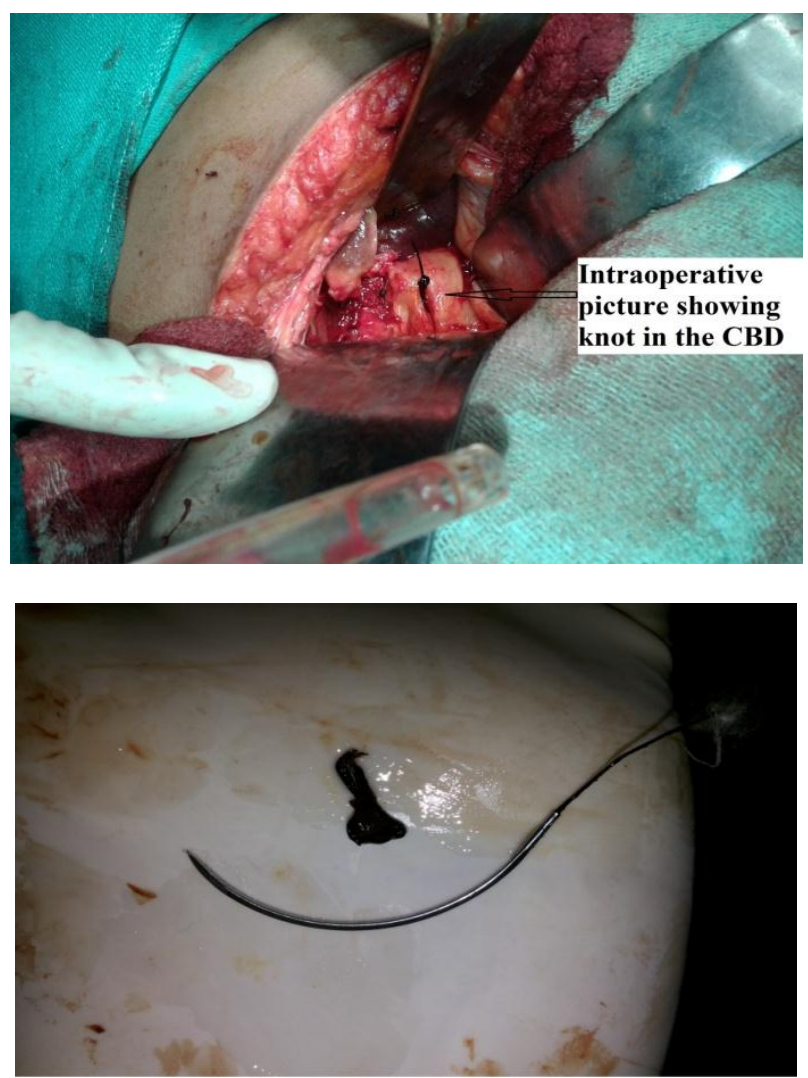

Removed suture knot 